\title{
Variation among populations in the resistance of Mytilus edulis embryos to copper: adaptation to pollution?
}

\author{
K. Hoare, A. R. Beaumont, J. Davenport* \\ School of Ocean Sciences, University of Wales, Bangor, Menai Bridge, Gwynedd, Wales LL57 5EY, UK
}

\begin{abstract}
The effects of copper on embryo development were found to differ between populations of the mussel Mytilus edulis L. (Mollusca: Bivalvia). Concentrations of copper which caused significantly increased rates of abnormality, and thus decreased yields of normal larvae, in populations from an unpolluted site (Menai Straits, Wales, UK) and to a lesser extent in an intermediately polluted site (Oosterschelde. The Netherlands) did not affect development of embryos from a polluted-site (Westerschelde, The Netherlands) population. Crosses indicated that tolerance was mostly maternally determined, but there is also evidence of a paternal, i.e genetic, effect. An appreciable quantity of background, non-treatment, embryo abnormality appeared to be sperm-mediated.
\end{abstract}

KEY WORDS: Embryos - Mussels · Copper Pollution - Adaptation - The Netherlands United Kingdom · Mytilus edulis

\section{INTRODUCTION}

Studies on the effects of copper on the mussel Mytilus edulis L. were surveyed by Davenport \& Redpath (1984). Although copper is an essential element for Mytilus spp., it is one of the most toxic of metals when in excess (Viarengo 1989). Copper concentrations in relatively unpolluted coastal waters are within the range 2 to $5 \mathrm{ppb}$ (Davenport \& Redpath 1984; ppb $=\mu \mathrm{g}^{-1}$ ), while Lewis \& Cave (1982) consider that concentrations of over about $30 \mathrm{ppb}$ are confined to the immediate locality of pollution sources.

Subcellular defence mechanisms involve complexation of the copper by highly affinitive substances such

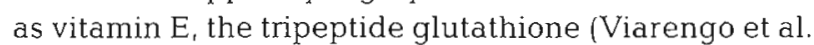
1989a) and metallothioneins (Viarengo et al. 1980, 1989b, Roesijadi et al. 1982). An increase of $15 \mathrm{ppb} \mathrm{Cu}$ over background levels causes mortality of $50 \%$ of adult Mytilus edulis in about $30 \mathrm{~d}$ (Manley 1980). Long-term exposure to sub-lethal concentrations causes pathological alterations in digestive, muscular

\footnotetext{
- Current address: University Marine Biological Station,
} Millport, Isle of Cumbrae, Scotland KA28 OEG, UK and reproductive tissues (Calabrese et al. 1984). Although pollutants can cause genetic damage in $M$. edulis (e.g. Brunetti et al. 1992), Sirover \& Loeb (1976) and Nacci et al. (1992) indicate that copper has limited genotoxicity. Pre-exposure to small amounts of copper can increase the resistance of adult mussels to higher concentrations (Davenport \& Manley 1978, Roesijadi \& Fellingham 1987), probably by stimulating the synthesis of metallothionein (Viarengo et al. 1980, Viarengo 1989).

Although copper-metallothionein induction has been demonstrated in Mytilus galloprovincialis (Viarengo et al. 1980) and Roesijadi \& Fellingham (1987) demonstrated that low-level copper, cadmium and zinc pre-exposure could protect $M$. edulis against mercury, no pollution-resistant natural populations of Mytilus spp. have yet been described.

Embryonic development is the most copper-sensitive stage in the life-cycle of Mytilus edulis; the $\mathrm{EC}_{50}$ (Effective Concentration at which $50 \%$ of control levels of normality are found) for production of normal ' $D$ ' larvae has been estimated to be $5.8 \mathrm{ppb}$ added copper by Martin et al. (1981) and 7.9 ppb added copper by Barnes (1989). Since these estimates of the $E C_{50}$ for 
normal development are well within the range of copper concentrations which may be found in polluted areas (Lewis \& Cave 1982), there might be considerable selection pressure exerted at the embryo stage on natural mussel populations in such areas.

Barnes (1989) found that copper reduced the yield of normal ' $D$ ' larvae by increasing the proportion of abnormal larvae rather than by decreasing overall survivorship. Abnormal larvae frequently appear to be unable to feed and usually die within a few days (Loosanoff \& Davis 1963). The experiments described in this paper compare the effects of copper on embryo development in mussels from sites of low, intermediate and high poilution exposure.

\section{MATERIALS AND METHODS}

Source populations, cultures and experiments. The source populations were chosen from sites where Mytilus edulis occurs intertidally in the absence of the closely related and hybridising species $M$. galloprovincialis Lmk. and $M$. trossulus Gould. (Gosling 1992). The 'clean' site source population was from Gallows Point (53 $15^{\circ} \mathrm{N}, 4^{\circ} 06^{\prime} \mathrm{W}$ ), Menai Strait, Wales, UK, an uncontaminated open coast site without significant riverine influence. Seawater copper concentrations in this area are in the region 3 to 5 ppb (Davenport \& Redpath 1984 , K.H. pers. obs.), although no data are available on tissue pollutant levels. The 'polluted' site source population was from Veerhaven $\left(51^{\circ} 26^{\prime} \mathrm{N}\right.$, $\left.4^{\circ} 03^{\prime} \mathrm{E}\right)$, Westerschelde, The Netherlands. The Westerschelde, part of the Rhine-Meuse delta system, forms the estuary of the River Schelde, the tributaries of which drain an area which includes Antwerp, Brussels and Ghent. Data on seawater metal levels in the delta area are not available, but mussels from Veerhaven and other sites in the Westerschelde have been shown to have high tissue concentrations of mercury, lead, chromium, arsenic, nickel, cadmium, copper, zinc (Luten et al. 1986, Stronkhorst 1992), polychlorinated biphenyls (PCB) and pesticides (Hummel et al. 1990, Stronkhorst 1992). A neighbouring estuary in the Rhine-Meuse delta system, the Oosterschelde, was almost completely closed off from riverine input by completion of the Volkerakdam in 1969 and is now, as a sea-arm, considered to be unpolluted by comparison with the Westerschelde. Mussel tissue metal and PCB levels have been shown to be lower now in the Oosterschelde than in the Westerschelde (Luten et al. 1986, Hummel et al.
1990). A mussel population at Kattendijke $\left(51^{\circ} 32^{\prime} \mathrm{N}\right.$, $3^{\circ} 58^{\prime} \mathrm{E}$ ), Oosterschelde, was therefore used as an 'intermediate' site source population. The riverine input at the sites influences pollutant exposure in 2 ways, directly by the pollutant content of the river water and indirectly by the increase in bioavailability of metals with reduced salinity.

Mytilus edulis were collected before the natural, early spring, spawning period, held in flowing Menai Strait seawater at $5^{\circ} \mathrm{C}$ and fed upon a mixture of algal species [Pavlova lutheri (Droop) Green, Rhinomonas reticulata (Lucas) Novarino, Tetraselmis chui Butcher and Skeletonema costatum (Grev.) Cleeve] until spawned. Mussels were induced to spawn by injection of $2 \mathrm{ml}$ of $0.5 \mathrm{M}$ potassium chloride ( $\mathrm{KCl}$ ) into the mantle cavity followed by emersion for 45 to $60 \mathrm{~min}$. They were then immersed in individual dishes of $0.2 \mu \mathrm{m}$ filtered UV-sterilised seawater (FSW) at $15^{\circ} \mathrm{C}$ (Bayne 1965). Spawning usually began within $1 \mathrm{~h}$. In one case it proved necessary to strip sperm, which involved cutting the mantle and diluting the resultant exudate with FSW. Eggs from all females which spawned were pooled and counted and approximately equal volumes of sperm from each male were mixed before insemination; see Table 1 for numbers of spawners. Sperm density was checked and a few minutes allowed for fertilisation to take place before the zygote suspension was divided equally between sterilised glass embryo dishes. These dishes contained FSW plus, where appropriate, enough 2 ppm copper solution (as copper chloride, $\mathrm{CuCl}_{2} \cdot 2 \mathrm{H}_{2}$ O) to give a final volume of $750 \mathrm{ml}$ at either 0 or $8 \mathrm{ppb}$ added copper. Beaumont et al. (1987) demonstrated that under these conditions copper concentrations do not fall by more than $25 \%$ over a $3 \mathrm{~d}$ exposure period. Initial embryo density was always between 350 and $700 \mathrm{~cm}^{-2}$ culture dish bottom area

Table 1. Spawnings carried out to assess the effect of added copper on the development of Mytilus edulis embryos from the Oosterschelde (OS), the Westerschelde (WS) and the Menai Strait (MS)

\begin{tabular}{|c|c|c|c|c|}
\hline Date & $\begin{array}{l}\text { Source of } \\
\text { parents }\end{array}$ & \multicolumn{2}{|c|}{ No. of parents } & $\begin{array}{l}\text { No. of replicates } \\
\text { per treatment }\end{array}$ \\
\hline \multicolumn{5}{|c|}{ Initial cultures } \\
\hline 14 Apr 1990 & OS & 3 & 6 & 6 \\
\hline 13 Jul 1990 & WS & 3 & 1 & 7 \\
\hline 16 Jul 1991 & MS & 10 & 6 & 7 \\
\hline \multicolumn{5}{|c|}{ Simultaneous spawnings } \\
\hline \multirow[t]{3}{*}{18 Apr 1992} & MS & 8 & 6 & 3 \\
\hline & OS & 5 & 5 & 2 \\
\hline & WS & 5 & 7 & 2 \\
\hline \multicolumn{5}{|l|}{ Crosses } \\
\hline 18 Apr 1992 & $\mathrm{MS} q \times \mathrm{WSO}^{*}$ & 8 & 7 & 2 \\
\hline 18 Apr 1992 & WSo $\times \mathrm{MSO}^{*}$ & 5 & 6 & 2 \\
\hline
\end{tabular}


(Barnes 1989). The dishes were left undisturbed at $15 \pm$ $1^{\circ} \mathrm{C}$ for $3 \mathrm{~d}$, until the embryos became ' $\mathrm{D}$ ' larvae. Numbers of normal and abnormal larvae were assessed for each dish by microscopical examination of 4 aliquots of the dish contents.

In order that the results might be relevant to the situation in the field, a level of copper within the range reported for coastal waters (Lewis \& Cave 1982) was used. The copper concentration chosen was $8 \mathrm{ppb}$ added copper. This is higher than reported $\mathrm{LD}_{50}$ values for embryo development (Martin et al. 1981, Barnes 1989) and higher than the acute $E_{50}$ for adult growth (Redpath 1985).

The effect of copper on total survivorships, percentage abnormalities and yields of normal 'D' larvae was determined for each of the Menai Strait, Oosterschelde and Westerschelde populations. In order to investigate embryo sensitivity to copper in more detail 2 further experiments were carried out. These were a simultaneous execution of the assay on embryos derived from all 3 of the populations and crosses between Westerschelde and Menai Strait parents. Table 1 gives details of the dates of the spawnings, numbers of parents and numbers of replicates involved in each experiment. The simultaneous assay involved testing the effects of $8 \mathrm{ppb}$ copper on embryos from each of the sites at the same time, to ensure that any differences in effect between populations seen during the original experiments were not due to the different timings of the experiments. The crosses involved using aliquots of the same mixtures of sperm and eggs from the parents from each site as were used in producing the 'pure' cultures, but using the Westerschelde sperm mixture to fertilise the Menai Strait egg mixture and vice versa. Comparison of these crosses with the 'pure' cultures produced at the same time, i.e. between cultures which differed only in the source of eggs or sperm, allowed separation of the maternal (cytoplasmic and genetic) and paternal (genetic only) influences. The mussels used in the simultaneous and cross spawnings were all kept in Menai Strait seawater for 5 mo before use; mortality during this time was negligible.

All experiments were carried out in accordance with the provisions of the Sea Fisheries (Shellfish) Act 1967 as varied by the Molluscan Shellfish (Control of Deposit) (Variation) Order 1983, S.I. no. 159.

Data analysis. The raw data were frequently found not to be normally distributed and were therefore statistically analysed using the Kruskal-Wallis and MannWhitney non-parametric tests (Siegel 1956).

\section{RESULTS}

\section{Differences in embryo sensitivity between populations}

The results are summarised in Table 2. Added copper has had a significant effect on the development of Menai Strait and Oosterschelde embryos, but no significant effect on the development of Westerschelde embryos. These effects are repeatable, being found both in the initial experiments and in the simultaneous exposure experiment carried out on mussels collected in a later spawning season.

The results from the initial experiments appeared to show differences among the source populations in the effect of $8 \mathrm{ppb}$ added copper on embryo development. However, these spawnings were carried out at different times, and therefore the differences may have been due to variation in, for example, water quality and background copper levels among spawnings. The results of the simultaneous exposure to $8 \mathrm{ppb}$ added copper of embryos from all 3 sites confirm that there are real differences among the populations in the resistance of embryos to copper challenge.

Table 2. Mytilus edulis. Survivorships, abnormalities and yields of normal larvae in embryo cultures from the Menai Strait (MS), the Oosterschelde (OS) and the Westerschelde (WS) reared at 8 ppb added copper. Results are expressed as percentages of controls without added copper

\begin{tabular}{|c|c|c|c|c|c|}
\hline $\begin{array}{c}\text { Source } \\
\quad ?\end{array}$ & $\begin{array}{c}\text { population } \\
\sigma^{8}\end{array}$ & Date & Total survivorship & Abnormality & $\begin{array}{l}\text { Yield of normal } \\
\text { veliger larvae }\end{array}$ \\
\hline MS & MS & 16 Jul 1991 & 88 & $114^{\circ}$ & $77^{\circ}$ \\
\hline MS & MS & 18 Apr 1992 & 96 & $257^{\cdots}$ & $51 \cdots$ \\
\hline OS & OS & 14 Apr 1990 & 77 & 133 & $70^{\circ}$ \\
\hline OS & OS & 18 Apr 1992 & 100 & $133^{\circ}$ & $28^{\circ}$ \\
\hline WS & WS & 13 Jul 1990 & 104 & 100 & 104 \\
\hline WS & WS & 18 Apr 1992 & 115 & 102 & 113 \\
\hline MS & WS & 18 Apr 1992 & 118 & $368^{*}$ & $13^{\cdots}$ \\
\hline WS & MS & 18 Apr 1992 & 95 & 105 & 94 \\
\hline
\end{tabular}


The reduction in yield of normal ' $\mathrm{D}$ ' larvae produced by exposure of Menai Strait or Oosterschelde embryos to $8 \mathrm{ppb}$ added copper is caused by an increase in the proportion of the larvae which develop abnormally, rather than by a reduction in total survivorship, i.e. rather than by a reduction in the numbers which develop at all to this stage. However, since abnormals do not survive, reductions in total survivorship and increases in percentage abnormality ultimately have the same effect.

\section{Crosses}

The results from the Menai Strait eggs $\times$ Westerschelde sperm cross (Table 2 ) are much more similar to those from the pure Menai Strait cultures than to those from the pure Westerschelde cultures, indicating that the maternal effects on embryo response to copper are much greater than the paternal effects.

Copper has had no significant effect on the Westerschelde eggs $\times$ Menai Strait sperm cross, and these results (Table 2) are thus far more similar to those for the pure Westerschelde cultures than to those for the pure Menai Strait cultures. The maternal influence is, again, much greater than the paternal influence.

The effects of sperm source on embryo development are summarised in Table 3. Comparison of the data from the Menai Strait eggs $\times$ Westerschelde sperm cross with the data from the pure Menai Strait cultures indicates that sperm source has had no significant effect at 0 ppb added copper. By contrast, at $8 \mathrm{ppb}$ added copper, there is significantly $(p<0.002)$ greater overall survivorship when Menai Strait eggs are fertilised with Westerschelde sperm than when they are fertilised by Menai Strait sperm. However, significantly $(p<0,002)$ more of these 'crosses' are abnormal, leading to a lower yield of normal ' $D$ ' larvae $(p<0.01)$ than in the 'pure' Menai Strait cultures.

Westerschelde eggs fertilised with Menai Strait sperm produced significantly fewer larvae at $3 \mathrm{~d}$, at both 0 and $8 \mathrm{ppb}$ added copper, giving significantly lower yields of normal larvae at both copper concentrations than Westerschelde eggs fertilised with Westerschelde sperm. However, percentage abnormality was significantly $(\mathrm{p}<0.001)$ lower at both 0 and 8 ppb when Westerschelde eggs were fertilised with Menai Strait sperm than when they were fertilised with Westerschelde sperm. The pure Westerschelde 0 ppb cultures showed a significantly $(\mathrm{p}<0.05)$ higher proportion of abnormals at 3 d than the pure Menai Strait $0 \mathrm{ppb}$ cultures. Westerschelde eggs fertilised with Menai Strait sperm had significantly lower percentage abnormalities than pure Westerschelde cultures, while Menai Strait eggs fertilised with Westerschelde sperm had significantly higher percentage abnormalities than pure Menai Strait cultures at $8 \mathrm{ppb}$, although not at $0 \mathrm{ppb}$. Overall, these effects of sperm source on abnormality suggest that an appreciable quantity of the non-copper-induced developmental abnormalities is sperm mediated.

The Westerschelde eggs $\times$ Menai Strait sperm cross had a low survivorship $(-10 \%)$ to $3 \mathrm{~d}$ at both 0 and $8 \mathrm{ppb}$ added copper, while both types of pure cultures produced at the same time from the same sources, and also the reverse crosses, had survivorships of over $50 \%$.

\section{DISCUSSION}

Direct comparison between different trials is complicated because of the influences of both egg and sperm sources on background mortalities and percentage

Table 3. Mytilus edulis. Effect of fertilisation of Menai Strait (MS) and Westerschelde (WS) mussel eggs with Menai Strait or Westerschelde population sperm on survivorships, abnormalities and yields of normal veliger larvae in cultures reared with and without $8 \mathrm{ppb}$ added copper. Survivorships and yields are expressed as percentages of the original number of eggs; abnormalities are expressed as a percentage of survivors

\begin{tabular}{|c|c|c|c|c|c|}
\hline $\begin{array}{c}\text { Source } \\
\wp\end{array}$ & $\begin{array}{c}\text { population } \\
\sigma^{3}\end{array}$ & $\begin{array}{l}\text { Copper } \\
\text { conc. }\end{array}$ & Survivorship & Abnormality & $\begin{array}{l}\text { Yield of normal } \\
\text { veliger larvae }\end{array}$ \\
\hline MS & MS & $0 \mathrm{ppb}$ & 82 & 23 & 63 \\
\hline MS & WS & $0 \mathrm{ppb}$ & 85 & 25 & 64 \\
\hline MS & MS & $8 \mathrm{ppb}$ & 79 & 59 & 32 \\
\hline MS & WS & $8 \mathrm{ppb}$ & $100 \cdots$ & $92 \cdots$ & $8 \cdots$ \\
\hline WS & WS & $0 \mathrm{ppb}$ & 52 & 49 & 26 \\
\hline WS & MS & $0 \mathrm{ppb}$ & $11 \cdots$ & $20 \cdots$ & $9^{\cdots}$ \\
\hline WS & WS & $8 \mathrm{ppb}$ & 60 & 50 & 30 \\
\hline WS & MS & $8 \mathrm{ppb}$ & $10^{\cdots}$ & $21 \cdots$ & $8 \cdots$ \\
\hline
\end{tabular}


abnormalities, which is why only trials differing in a single factor, i.e. the presence or absence of copper or the source of the eggs or sperm, can be compared. The comparatively high level of embryonic abnormalities associated with Westerschelde sperm (Table 3) may be an indication of cytogenetic damage or abnormalities in sperm head morphology (Dixon 1983), although Westerschelde eggs are not associated with higher abnormality levels than are eggs from other sites.

While the observed effects of $8 \mathrm{ppb}$ added copper on Menai Strait embryos agree with those found by Martin et al. (1981) and Barnes (1989) for Mytilus edulis, embryos derived from populations which have experienced high levels of pollution are less severely affected. The statistical difference in yield of ' $D$ ' larvae between the $8 \mathrm{ppb}$ treatment groups and the $0 \mathrm{ppb}$ controls is insignificant for the Westerschelde population, significant at $\mathrm{p}<0.05$ for the Oosterschelde population and significant at $p<0.002$ for the Menai Strait population. The relative levels of embryo resistance to copper thus correlate well with the relative levels of pollution experienced by the source populations, and suggest that some physiological and/or genetic adaptation is occurring. This adaptation is not necessarily specifically related to environmental copper concentrations; as mentioned below, physiological detoxification mechanisms such as the production of metallothioneins are effective against a range of metals

A similar difference was seen in the effect of $8 \mathrm{ppb}$ added copper on the embryo development of the selffertile hermaphrodite mytilid Semimytilus algosus from Herradura and Tongoy Bays, Chile, sites of high and low pollution respectively (Hoare 1993). Such an influence of parental experience on embryo response has been demonstrated previously by Haley et al. (1976), who tested the effects of different salinities on embryos of the oyster Crassostrea virginica.

The crosses between Menai Strait and Westerschelde mussels were carried out in an attempt to demonstrate whether there was a genetic component to the adaptation. Embryonic development in Mytilus spp. is largely controlled by maternal developmental determinants; transcription of the zygotic genome in molluscs probably does not begin until gastrulation (Firtel \& Monroy 1970, Kidder 1976). The influence of the sperm genome on embryo development is therefore likely to be limited. However, a more definite indication of the genetic component to the adaptation would only be possible if offspring produced from Westerschelde parents were to be grown on to maturity in unpolluted conditions and the F2 generation submitted to the copper toxicity assay. The results from the crosses do demonstrate that the main influence on embryo resistance to copper is maternal; this is not unexpected given that the maternal contributions to the embryo are both genetic and cytoplasmic, while the paternal contribution is purely genetic. There is, however, also some evidence for a paternal, i.e. genetic, effect. This paternal effect is shown in the difference in response between Menai Strait eggs fertilised by Westerschelde sperm and pure Menai Strait embryos when both are cultured with $8 \mathrm{ppb}$ added copper (Table 3), although the situation is complicated by the influence of sperm source on embryo abnormalities. The precise effect of this proposed genetic component to embryo copper resistance is not yet known. Although veliger larvae may be capable of producing metallothioneins in response to metal stress (Roesijadi et al. 1982, Ringwood 1992), metallothionein induction in the embryo is unlikely to be possible before activation of the zygotic genome at gastrulation. Metallothionein-like proteins have, however, been found in unfertilised sea-urchin eggs (Ohtake et al. 1983); the greater resistance of Westerschelde mussel embryos may be a result of inheritance of maternal metallothioneins. The extent of any such inheritance or induction of copper metallothioneins in the embryos and veligers of $M$. edulis is as yet unclear. Roesijadi et al. (1982) exposed mature $M$. edulis to mercury for 2 wk immediately before spawning and found mercury metallothioneins in the resulting ' $D$ ' larvae. However, since a small amount of mercury was found to have been passed on to the larvae in the egg cytoplasm, there is doubt as to whether the veliger metallothionein was autogenous or inherited. Although there was some inheritance of mercury in this case (Roesijadi et al. 1982), there is evidence that developmental transmission of metals does not usually occur under chronic exposure; Grieg et al. (1975) found that Crassostrea virginica from polluted areas, with high tissue concentrations of copper and cadmium, produced eggs which had metal levels similar to those in eggs produced by oysters at a clean site with low tissue metal concentrations. Amiard et al. (1986) found metal levels in Mytilus edulis gonad to be lower than in the somatic tissues.

The embryo sensitivity differences among the 3 source populations persist even when the parents are all kept under the same conditions, in Menai Straits water, for 5 mo prior to spawning. Maintenance of tolerance differences among individuals in the absence of the contaminant has been taken as evidence of genetic adaptation (e.g. Bryan \& Hummerstone 1971), but we have found no published data on the persistence of physiological adaptation in mussels after removal of the causative agent. Metallothionein persistence, perhaps associated with the long half-life in mussel tissues of some metals (e.g. 7 mo for cadmium; Viarengo 1989) combined with the lack of metal specificity of metallathioneins (Roesijadi \& Fellingham 1987), means that 
inherited physiological adaptation could be involved in differential embryo responses to copper even after 5 mo of parental acclimation to unpolluted conditions. It is therefore not possible to state exactly how much of the difference between populations is due to genetic differences and how much due to other factors. In a review of the literature on genetic adaptation to heavy metals in aquatic organisms, Klerks \& Weis (1987) discussed the probable relative contributions of genetic and physiological factors in each study. They concluded that, in single-generation studies, the 2 adaptive mechanisms are frequently confused.

Clear instances of genetic adaptation to pollutants are given by breeding studies, where resistance is found in F2 and later generation offspring of resistant individuals cultured in the absence of the original pollutant. There are a few such studies on aquatic invertebrates (Bryan \& Hummerstone 1971, Brown 1976. Klerks \& Levinton 1989) and these tend to show the same speed of evolution of tolerance to metals as has been found for land plants (Shaw 1989). In plants these resistances have been found to be highly heritable (McNeilly \& Bradshaw 1968, Macnair 1989), and, although variation in metal resistance is found in both tolerant and non-tolerant populations (Lefebvre \& Vernet 1989), sharp resistance boundaries can be maintained over centuries between contaminated site populations and their neighbours, even when demonstrable gene flow takes place (McNeilly \& Bradshaw 1968).

Acknowledgements. We thank Herman Hummel and Roelof Bogaards of the Netherlands Institute for Hydrobiological Research, Yerseke, for mussels and pollution data from the Delta. This study was funded by the Science and Engineering Research Council.

\section{LITERATURE CITED}

Amiard, J. C., Amiard-Triquet, C., Berthet, B., Metayer, C. (1986). Contribution to the ecotoxicological study of cadmium, lead, copper and zinc in the mussel Mytilus edulis I. Field study. Mar. Biol. 90:425-431

Barnes, D. A. (1989). The effects of initial egg density and added copper concentration on the development of early larval stages of the mussel Mytilus edulis. M.Sc. thesis, University of Wales, Bangor

Bayne, B. L. (1965). Growth and the delay of metamorphosis of the larvae of Mytilus edulis (L.). Ophelia 2: 1-47

Beaumont, A. R., Tserpes, G., Budd, M. D. (1987). Some effects of copper on the veliger larvae of the mussel Mytilus edulis and the scallop Pecten maximus (Mollusca Bivalvia). Mar. environ. Res. 21. 299-309

Brown, B. E. (1976). Observations on the tolerance of the isopod Asellus meridianus Rac to copper and lead. Water Res. 10: $555-559$

Brunetti, R., Gabrıele, M., Valerio, P., Fumagalli, O. (1992) The micronucleus test: temporal pattern of baseline frequency in Mytilus galloprovincialis. Mar. Ecol. Prog. Ser. 83: $75-78$
Bryan, G. W., Hummerstone, L. G. (1971). Adaptation of the polychaete Nereis diversicolor to estuarine sediments containing high concentrations of heavy metals. I. General observations and adaptation to copper. J. mar. biol. Ass. U.K. 51. 845-863

Calabrese, A., MacInnes, J. R., Nelson, D. A., Greig, R. A., Yevich, P. P. (1984). Effects of long-term exposure to silver or copper on growth, bioaccumulation and histopathology in the blue mussel Mytilus edulis. Mar. environ. Res. 11. $253-274$

Davenport, J., Manley, A. (1978). The detection of heightened sea-water copper concentrations by the mussel Mytilus edulis. J. mar. biol Ass. U.K. 58: 843-50

Davenport, J., Redpath, K. J. (1984). Copper and the mussel Mytilus edulis L. In: Bolis, L., Zadunaisky, J., Gilles, R. (eds.) Toxins, drugs and pollutants in marine animals. Springer-Verlag, Berlin, p. 176-189

Dixon, D. R. (1983). Methods for assessing the effects of chemicals on reproductive function in marine molluscs. In: Vouk, V. B., Sheehan, P. J. (eds.) Methods for assessing the effects of chemicals on reproductive functions, Scientific Committee on Problems of the Environment, Series 20. Wiley, New York, p. 439-457

Firtel, R. A., Monroy, A. (1970). Polysomes and RNA synthesis during early development of the surf clam Spisula solidissima. Dev. Biol. 21: 87-104

Gosling, E. (ed.) (1992). The mussel Mytilus: ecology, physiology, genetics and culture. Developments in aquaculture and fisheries science 25. Elsevier, Amsterdam

Grieg, R. A., Nelson, B. A., Nelson D. A. (1975). Trace metal content in the American oyster. Mar. Pollut. Bull. 6: 72-73

Haley, L. E., Newkirk, G. F., Waugh, D. W., Doyle, R. W. (1976). A report on the quantitative genetics of growth and survivorship of the American oyster Crassostrea virginica under laboratory conditions. In: Persoone, G., Jaspers, E. (eds.) Proc. 10th Eur. Symp. Mar. Biol., Vol. 1, Mariculture. Universa, Wetteren, p. $221-228$

Hoare, K. (1993). Effects of copper on populations of the mussel, Mytilus edulis L. Ph.D. thesis, University of Wales, Bangor

Hummel, H., Bogaards, R. H., Nieuwenhuize, J,, De Wolf, L., Van Liere, J. M. (1990). Spatial and seasonal differences in the PCB content of the mussel Mytilus edulis. Sci. tot. Environ. 92: 155-163

Kidder, G. M. (1976). RNA synthesis and the ribosomal cistrons in early molluscan development. Am. Zool. 16. $501-520$

Klerks, P. L., Levinton, J. S. (1989). Rapid evolution of metal resistance in a benthic oligochaete inhabiting a metalpolluted site. Biol. Bull. 176: 135-141

Klerks, P. L., Weis, J. S. (1987). Genetic adaptation to heavy metals in aquatic organisms: a review. Environ. Poll. 45 $173-205$

Lefebvre, C., Vernet, P. (1989). Microevolutionary processes on contaminated deposits. In: Shaw, A. J (ed.) Heavy metal tolerance in plants: evolutionary aspects. CRC Press, Boca Raton, p. 285-299

Lewis, A. G., Cave, W. R. (1982). The biological importance of copper in oceans and estuaries. Oceanogr. mar. Biol. A. Rev. 20: 471-695

Loosanoff, V. L., Davis, H. C. (1963). Rearing of bivalve molluscs. Adv. mar. Biol. 1: 1-136

Luten, J. B., Bouquet, W., Burggraaf, M. M., Rauchbaar, A. B., Rus, J. (1986). Trace metals in mussels (Mytilus edulis) from the Waddenzee, coastal North Sea and the estuaries of Ems, Western and Eastern Scheldt. Bull. environ. Contam. Toxicol. 36: 770-777 
Macnair, M. R. (1989). The genetics of metal tolerance in natural populations. In: Shaw, A. J. (ed.) Heavy metal tolerance in plants: evolutionary aspects. CRC Press, Boca Raton, p. 235-253

Manley, A. R. (1980). The responses of marine bivalves to selected heavy metals. Ph.D. thesis, University of Wales, Bangor

Martin, M., Osborn, K. E., Billig, P., Glickstein, N. (1981). Toxicities of ten metals to Crassostrea gigas and Mythlus edulis embryos and Cancer magister larvae. Mar. Pollut. Bull. 12: 305-308

McNeilly, T., Bradshaw, A. D. (1968). Evolutionary processes in populations of copper tolerant Agrostis tenuis Sibth. Evolution 22: 108-18

Nacci, D., Nelson, S., Nelson, W., Jackim, E. (1992). Application on the DNA alkaline unwinding assay to detect DNA strand breaks in marine bivalves. Mar. environ. Res. 33: $83-100$

Ohtake, H., Suyemitsu, T., Koga, M (1983). Sea-urchin (Anthocidaris crassispina) egg zinc-binding protein: cellular localization, purification and characterization. Biochem. J. 211: 109-118

Redpath, K. J (1985). Growth inhibition and recovery in mussels (Mytilus edulis) exposed to low copper concentrations. J. mar. biol. Ass. U.K. 65: 421-431

Ringwood, A. H. (1992). Effects of chronic cadmium exposures on growth of larvae of an Hawaiian bivalve, Isognomon californicum. Mar. Ecol. Prog. Ser. 83: 63-70

Roesijadi, G., Calabrese, A., Nelson, D. (1982). Mercurybinding proteins of Mytilus edulis. In: Vernberg. $W$ B., Calabrese, A., Thurberg, F. P., Vernberg, F. J. (eds.) Physiological mechanisms of manne pollutant toxicity. Academic Press, New York, p. 75-87

This article was presented by D. S. McLusky (Senior Editorial Advisor), Stirling, UK
Roesijadi, G., Fellingham, G. W. (1987). Influence of Cu, Cd and $\mathrm{Zn}$ preexposure on $\mathrm{Hg}$ toxicity in the mussel Mytilus edulis. Can J. Fish. Aquat. Sci. 44:680-684

Shaw, A. J (ed.) (1989). Heavy metal tolerance in plants: evolutionary aspects. CRC Press, Boca Raton

Slegel, S. (1956). Non-parametric statistics for the behavioural sciences. McGraw-Hill, New York

Sirover, M. A., Loeb, L. A. (1976). Infidelity of DNA synthesis in vitro: screening for potential metal mutagens or carcinogens. Science 194: 1434-1436

Stronkhorst, J. (1992). Trends in pollutants in blue mussel Mytilus edulis and flounder Platichthys flesus from two Dutch estuaries, 1985-1990. Mar. Pollut. Bull. 24 $250-258$

Viarengo, A. (1989). Heavy metals in marine invertebrates: mechanisms of regulation and toxicity at the cellular level. Rev. aquat. Sci. 1: 295-317

Viarengo, A., Pertica, M., Canesi, L., Accomando, R., Mancinelli, G., Orunesu, M. (1989a). Lipid peroxidation and level of antioxidant compounds (GSH, Vitamin E) in the digestive glands of mussels of three different age groups exposed to anaerobic and aerobic conditions. Mar. environ. Res. 28: 291-295

Viarengo, A., Pertica, M., Canesi, L., Mazzucotelli, A., Orunesu, M., Bouquegneau, J. M. (1989b). Purification and biochemical characterization of a lysosomal copperrich thionein-like protein involved in metal detoxification in the digestive gland of mussels. Comp. Biochem. Physiol 93C: $389-395$

Viarengo, A., Pertica, M., Mancinelli, G., Zanicchi, G. Orunesu, M. (1980). Rapid induction of copper-binding proteins in the gills of metal exposed mussels. Comp. Biochem. Physiol. 67C: 215-218

Manuscript first received: June 6, 1994

Revised version accepted: December 6, 1994 